This item was submitted to Loughborough's Research Repository by the author.

Items in Figshare are protected by copyright, with all rights reserved, unless otherwise indicated.

\title{
The desired qualities of customer contact employees in complaint handling
} encounters

PLEASE CITE THE PUBLISHED VERSION

http://dx.doi.org/10.1362/026725706777978721

PUBLISHER

Routledge / Taylor \& Francis (@ Westburn Publishers Ltd)

VERSION

AM (Accepted Manuscript)

LICENCE

CC BY-NC-ND 4.0

REPOSITORY RECORD

Gruber, Thorsten, Isabelle Szmigin, and Roediger Voss. 2019. "The Desired Qualities of Customer Contact Employees in Complaint Handling Encounters”. figshare. https://hdl.handle.net/2134/11920. 
This item was submitted to Loughborough's Institutional Repository (https://dspace.lboro.ac.uk/) by the author and is made available under the following Creative Commons Licence conditions.

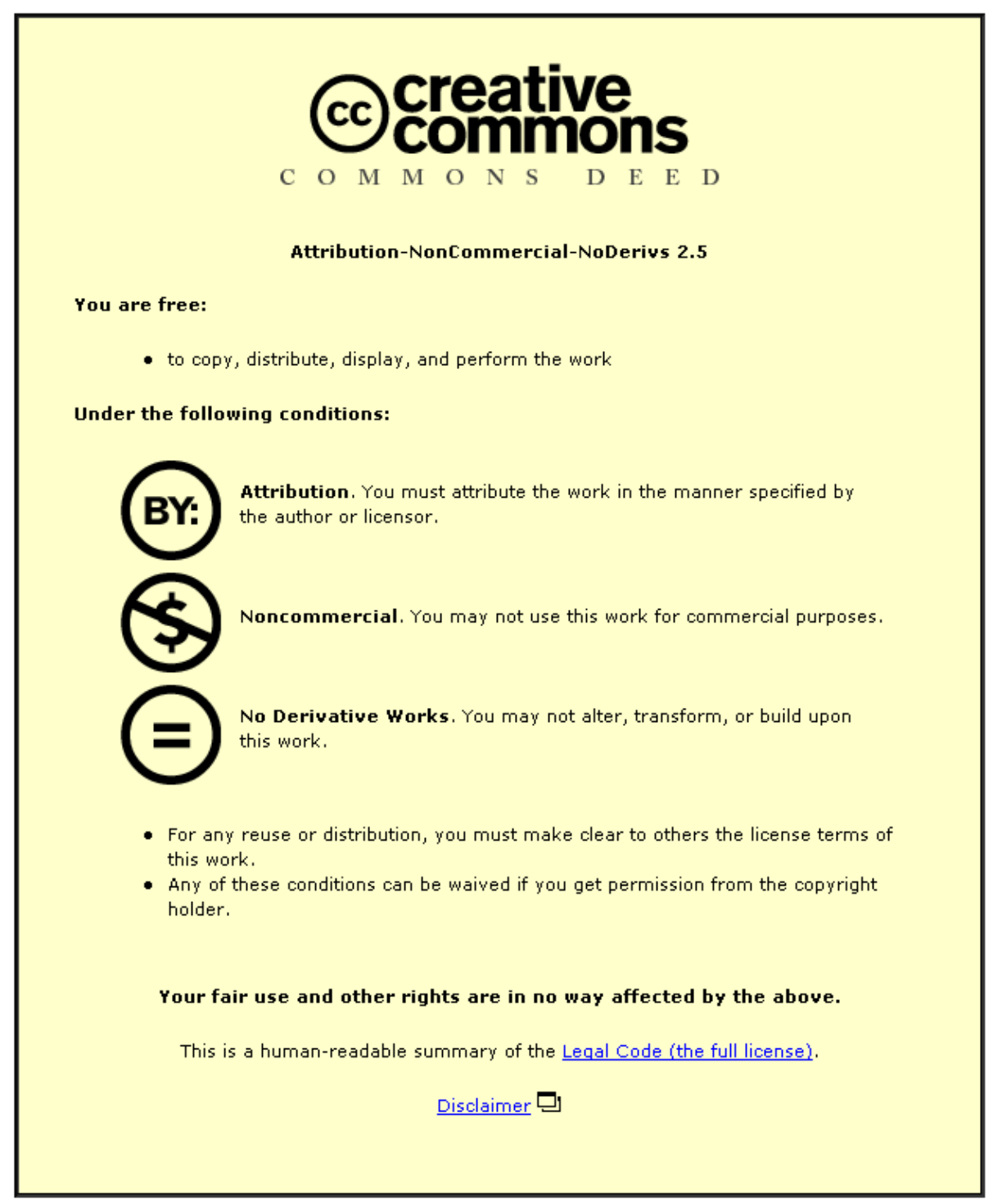

For the full text of this licence, please go to: http://creativecommons.org/licenses/by-nc-nd/2.5/ 


\title{
The Desired Qualities of Customer Contact Employees
}

in Complaint Handling Encounters

\author{
Thorsten Gruber and Isabelle Szmigin \\ The Birmingham Business School \\ University House
}

Birmingham B15 2TT, UK

\author{
Roediger Voss \\ University of Education Ludwigsburg \\ Pädagogische Hochschule Ludwigsburg \\ Institut für Bildungsmanagement \\ Postfach 220, 71602 Ludwigsburg
}

Germany

Send correspondence to: Thorsten Gruber, The Birmingham Business School

University House, Birmingham B15 2TT, UK

Tel: ++49-(0)174-4853581

(thorsten.gruber@gmail.com) 


\begin{abstract}
This paper explores the nature of complaint satisfaction with a particular emphasis on the qualities and behaviours that affect customers during the personal complaint handling encounter. The paper reviews the literature on complaint satisfaction and the role of the contact employee in the complaint encounter. An empirical study using the means-end approach and the paper-and-pencil version of the laddering technique provides a deeper understanding of attributes of effective customer contact employees and reveals the underlying benefits that complainants look for. The research indicates that complainants want contact employees to give positive nonverbal signals, to have sufficient product (service) knowledge and the authority to handle their problems adequately. They also want employees to be willing to try hard and spare no effort. Customers think that if employees take them seriously, this will lead to a problem solution and feelings of satisfaction. The paper concludes with suggestions to managers to introduce and improve active complaint management and reviews the limitations of the research method.
\end{abstract}

\title{
Keywords: means-end, laddering, desire expectations, complaint satisfaction, customer contact employees
}

\section{Biography}

Thorsten Gruber is a postdoctoral research assistant at the University of Birmingham and a part-time visiting lecturer at the University of Education Ludwigsburg. He received his Ph.D. and holds an MBA from the University of Birmingham. His research interests include consumer complaining behaviour, services marketing and electronic commerce. He has published in journals such as Management Services and Empirische Pädagogik. He is also the managing director of the consultancy Endeavour-Marketing\&Research. 
Isabelle Szmigin is Professor of Marketing at the University of Birmingham from where she gained her $\mathrm{PhD}$. She has extensive publications in the fields of consumer behaviour, consumer innovativeness, services management and relationship marketing, including a recent book, Understanding the Consumer.

Rödiger Voss is a lecturer at the University of Education Ludwigsburg. He received his Ph.D. from the University of Education Ludwigsburg. His research interests include marketing of higher education, services marketing and consumer behaviour. He has published in journals such as Management Services, Planung \& Analyse, QZ - Qualität und Zuverlässigkeit, and Empirische Pädagogik. 


\section{Introduction}

In the quest to establish successful long-term relationships, the need to avoid the negative consequences of dissatisfaction and the high costs of acquiring new customers should be paramount to companies (Hart et al. 1990). Yet the evidence shows that complaints are still badly handled. Estimates suggest that fewer than $50 \%$ of complainants receive a response from the company and when they do it is such that the customer is not satisfied (Naylor 2003). Lewis and McCann (2004) examined service failure and recovery in the hotel industry and found that only just over $50 \%$ of their respondents were satisfied or very satisfied with how the hotel had dealt with their problem. Similarly, Holloway and Beatty (2003) found that the majority of customers in two US studies on service failure in online retailing felt injustice following the company's recovery efforts.

Disappointed customers are a threat to a company, as they may switch to competitors and engage in negative world of mouth (Blodgett et al. 1995). In Holloway and Beatty's study the majority of the dissatisfied customers said they would not shop with the company again. Despite these findings, companies still invest little in terms of retaining their customers (Cranage 2004), yet earlier research clearly supports the view that existing customers ask fewer questions, have more realistic expectations, are more familiar with company employees and products, and have lower price sensibility than new customers (Reichheld and Sasser 1990).

In this paper we seek to investigate the nature of complaint satisfaction and in particular what qualities and behaviours affect the customer during the personal complaint handling encounter. The paper begins by reviewing the literature on complaint satisfaction and the role of the contact employee in the complaint encounter, it then presents a study using laddering questionnaires to develop a deeper understanding of the attributes of effective customer contact employees. The study uncovers constructs that underlie customers' desire 
expectations and the paper concludes with a discussion of the nature of the constructs and the implications the findings have for management and further research.

\section{The Nature of Complaint Satisfaction and the Role of Employees}

Complaining customers offer an opportunity for the company to solve a problem and reduce the likelihood of dissatisfied customers switching to a competitor and engaging in negative word of mouth (Stauss 1999). A company which effectively handles its complaints is more likely to maintain its customer relationships (Boshoff and Allen 2000) and even turn dissatisfaction into positive support for the company (Hennig-Thurau 1999; Stauss 1999). Stauss (2002, p. 174) defines complaint satisfaction in general terms as "the satisfaction of a complainant with a company's response to her/his complaint". Complaint satisfaction is a subjective evaluation process; an analogy can be made to the expectations-disconfirmation paradigm (Parasuraman et al. 1985), as customers will compare their expectations concerning the company's complaint handling activities with their perceptions. Customers will be satisfied if the complaint handling experience exceeds their expectations and dissatisfied if the company cannot meet their expectations. Customers will be neither satisfied nor dissatisfied but indifferent if their perceptions equal their expectations. Companies need to know what complaining customers expect and how customer contact employees can meet or exceed customer expectations to recover and strengthen the endangered relationship. Knowing what customers expect should enable the organisation to ensure that their contact employees adapt their behaviour to customers' underlying expectations, which should have a positive impact on customer satisfaction (Botschen et al. 1999).

Customer contact employees act as key determinants of the customer's perception of the service (Hartline and Ferrell 1996) and play a critical role in the recovery from failure (Boshoff and Allen 2000; Maxham III and Netemeyer 2003). Research indicates that 
employees who are capable and competent to solve a problem may improve the service encounter (Bitner et al. 1990). Importantly frontline employees exert an influence on how the service is perceived before, during and after purchase (Chung-Herrera et al. 2004; Van Dolen et al. 2004). A key aim of this paper is to examine from the complaining customer's perspective, how contact employees should behave and which qualities they should possess (desire expectations). Customer expectations and particularly desire expectations have received relatively little attention (Pieters et al. 1998; Yim et al. 2003). Desire expectations may be used as reference points for satisfaction judgements (Singh and Widing II 1991) and to evaluate the recovery performance of service providers (Yim et al. 2003). They are thought to be more stable and less dependent on the particular service situation than other types of expectations (Zeithaml et al. 1993) and so examining the nature of desire expectations should make an important contribution to the area of complaint satisfaction.

Understanding of complaint satisfaction is also limited (Kim et al. 2003). Research on consumer complaints has focused on identifying variables that influence complaining behaviour such as the likelihood of successful redress (Singh 1990), attribution of blame (Folkes 1984), the customer's attitude toward complaining (Richins 1982) and the characteristics of complaining customers (McAlister and Erffmeyer 2003). Little is known about how customers evaluate recovery approaches and the parameters of success in terms of turning dissatisfied into satisfied customers (Holloway and Beatty 2003; McCollough et al. 2000). What is needed is a better understanding of the customer's point of view in terms of what is required in contact employee behaviour during the complaint handling encounter.

Recent work by Wirtz and Mattila (2004) found that satisfaction acts as a mediator variable between post-recovery behaviours (negative word-of-mouth communication and repurchase intention) and service recovery dimensions. They recognised the need for further research which looks at satisfaction as the main dependent variable. Therefore another aim of 
this paper is to suggest how customer contact employees should behave and what qualities they should possess to create complaint satisfaction in face to face encounters.

The study's objective was to develop a deeper understanding of the attributes (qualities and behaviours) of effective customer contact employees that complaining customers desire and to uncover the constructs that underlie these desire expectations. The study used a semistandardised qualitative technique called laddering which to date has not been applied in the investigation of complaint handling and complaint satisfaction. It is, however, particularly appropriate to this research area as we explain below.

\section{The Means-End Approach and the Laddering Technique}

The means-end approach allows researchers to examine the consumer's individuality in depth while still producing quantifiable results. Although originally used for product or brand positioning issues (Gutman 1982; Olson and Reynolds 1983), in succeeding years it has been applied to a range of areas including consumer behaviour (e.g. Bagozzi and Dabholkar 1994; Pieters et al. 1995; Pieters et al. 1998), sales management (e.g. Botschen et al. 1999; DeeterSchmelz et al. 2002; Reynolds et al. 2001), and strategic marketing (e.g. Norton and Reynolds 2001; Reynolds and Rochon 2001).

The rationale of Botschen et al.'s (1999) study was that the behaviours of sales personnel are the means by which customers satisfy or strengthen their personal goals and values. Through examining the characteristics and behaviours of sales people sought by customers, behaviour could be adapted to match customers' expectations. Pieters et al. (1998) examined customers' desired expectations of service employees, suggesting that the ability of a customer to attain his personal goals and values (the ends) is at least partly dependent on the behaviour (the means) of service employees. 
These examples show how the means-end chain approach attempts to discover the salient meanings that consumers associate with products, services and behaviours. The focus is on the associations in the consumer's mind between the attributes of products, services or behaviours, which are the "means", the consequences of these attributes for the consumer, and the personal values or beliefs, the "ends", which are satisfied by the consequences. While the attributes are the characteristics of a product or service, the consequences are the reasons why an attribute is important. They are the psychological or physiological aspects which motivate a customer to use a product or service (Gutman 1982). Values are a more universal concept and may be considered as life goals; personal and general consequences individuals are striving for in their lives (Rokeach 1973). The linkages between attributes, consequences and values are what produce the means-end chains (Peter et al. 1999). Consumer knowledge is assumed to be hierarchically organised in the consumer's memory spanning different levels of abstraction (Reynolds et al. 1995); the higher the level of abstraction, the stronger the connection to the self. Thus a hierarchy exists with attributes (low level of abstraction) as less relevant to the self than consequences (mid level of abstraction) and values being of most relevance (high level of abstraction) (Olson and Reynolds 1983).

The means-end approach relies on two premises (Manyiwa and Crawford 2002): values have a significant impact on (buying) behaviour, and consumers classify products and services into sets to make the choice-making process easier. The means-end approach has its roots in Kelly's Personal Construct Psychology (1991/1955). Kelly believed that individuals have their own view of the world and are able to reflect on and control their behaviour by creating rules or developing theories. In the means-end approach a consumer's understanding of how elements of the world relate to them are be represented through means-end chains (Gengler et al. 1995).

Grunert and Grunert (1995) distinguish between two views of the means-end approach. According to the motivational view, means-end chains and laddering should help the 
researcher learn about the consumers' buying motives. The cognitive structure view, advocated by others (Gutman 1982; Reynolds and Gutman 1988) proposes that means-end chains should be regarded as modelling consumption-relevant cognitive structures. Here knowledge relevant to consumption is stored and organised in the memory (Grunert and Grunert 1995). In accordance with the cognitive view of human beings, cognitive structures and cognitive processes interact and control human behaviour (Grunert and Grunert 1995). Cognitive structures are often displayed as networks of cognitive categories and the linkages between them. Extracts from the cognitive structure are linear such that the cognitive concepts are linked by one-to-one associations. This linear structure is worked out by the researcher from a possibly larger cognitive network during the laddering process (Grunert and Grunert 1995). The hierarchical approach has been criticised by Herrmann (1996) citing modern cognitive psychology research as suggesting that cognitive structures are complex networks. Others recommend that knowledge representations should be viewed as association patterns or semantic networks (Chang 1986; Van Rekom and Wierenga, 2002). Here consumers have patterns of interconnected concepts in their minds where the resultant network may be more critical than the hierarchies within. Olson and Reynolds (2001) emphasise that what is most important to study is the connections between components (attributes, consequences, values). These views suggest that we should be more interested in the relations between the concepts of meaning than the hierarchy of concepts.

\section{The Research Study}

There are two different laddering approaches that can be distinguished: soft laddering and hard laddering (Botschen and Thelen 1998; Grunert et al. 2001). Soft laddering refers to indepth interviews where respondents are restricted as little as possible in their natural flow of speech. Researchers have to understand the meaning of the given answers and to link them to 
the means-end model (Grunert et al. 2001). Hard laddering uses data collection techniques such as structured interviews and questionnaires where respondents will be led to "produce ladders one by one and to give answers in such a way that the sequence of the answers reflects increasing levels of abstraction" (Grunert et al. 2001, p. 75). While the majority of published means-end chain studies have used in-depth laddering interviews, there has been some use of questionnaires to collect laddering data. For example Walker and Olson (1991) developed a paper-and-pencil version of the laddering interview. Here the researcher asks respondents to fill in a structured questionnaire writing down up to four relevant attributes and then specify why a certain attribute is important to them. For each attribute, respondents can give up to three reasons.

Botschen and Hemetsberger (1998) believe that this version reduces interviewer bias and negates social pressure such that respondents can decide when they want to end the laddering process. According to Botschen et al. (1999), the major advantage of the paper-and-pencil version in comparison to the traditional in-depth interviewing technique is the cost-efficient collection of data. It is also easier to manage and it takes less time to collect and analyse laddering data compared to soft laddering. Several researchers (e.g. Botschen and Hemetsberger 1998; Botschen and Thelen 1998; Goldenberg et al. 2000; Pieters et al. 1995) have already employed the paper-and pencil version successfully. Thus, in this study we decided to use questionnaires instead of conducting personal interviews. Each respondent received a detailed laddering explanation developed from existing instructions (Botschen and Hemetsberger 1998; Pieters et al. 1998). The following figures present the laddering instructions that helped respondents fill in the questionnaires and the laddering questionnaire that was used in our research study:

(Take in Figure 1) 
(Take in Figure 2)

The study was conducted between September and November 2005 amongst university postgraduate students at a large European University. Laddering questionnaires were handed out to 40 students aged between 19 and 39 years $(X=24.3)$ enrolled in two business management courses who took part on a voluntary basis. The number of distributed questionnaires was theory-driven on the basis of sampling to achieve theoretical saturation. Theoretical saturation means that no new, or relevant data emerges concerning a category, that the category is well-developed, and that the linkages between categories are wellestablished (Strauss and Corbin 1998). The problem for qualitative researchers is that they do not know the minimum sample size at the beginning of a study (Bryman 2004). We originally planned to hand out 68 laddering questionnaires in three courses. After having analysed the filled in questionnaires from the first two courses, however, we discovered that respondents did not provide any new categories. As our categories reached theoretical saturation, we decided that no additional questionnaires were necessary from the third course and we stopped the laddering process after 40 questionnaires. The following table details the characteristics of the sample:

(Take in Table 1)

\section{Data Analysis and Results}

Meaningful categories were developed to group together phrases with identical meanings. We broke down the raw laddering data into separate phrases (chunks of meaning). We then developed meaningful categories so that we were able to group comparable phrases with identical meaning together. Using the decision-support software programme, LADDERMAP 
(Gengler and Reynolds 1993) we entered up to ten chunks of meaning per ladder and categorised each phrase as either an attribute, a consequence, or a value (Gengler and Reynolds 1995). The software allowed us to change and review the content analysis without difficulty and quickly alter coding. The following tables show the 15 attributes, 15 consequences, and 8 values that resulted from our content analysis. The codes are listed in descending order, based on the frequency of mention in the ladders.

(Take in Tables 2, 3, and 4)

We then used LADDERMAP to create implication matrices and a hierarchical value map. An implication matrix "bridges the gap between the qualitative and quantitative aspects of the laddering technique" (Deeter-Schmelz et al. 2002, p. 619) by showing the number of times one code leads to another. Rows represent the respondents' ladders, while columns correspond to the elements within the ladders. It is called an implication matrix as the associations between the constructs are generally labelled as "implications". An implication matrix generally displays two different types of implications: in a direct implication one attribute/consequence is stated directly after another attribute/consequence in the same ladder, without any intervening attributes/consequences. In an indirect implication two attributes/consequences are stated in the same ladder but separated by at least one intervening attribute/consequence. The following table shows an extract from the implication matrix:

(Take in Table 5)

The number of direct relations is given to the left of the decimal and total implications (direct and indirect relations) are expressed to the right of the decimal. For example, "competence" leads to "complaint handling" 10 times directly and 12 times indirectly (22-10). Thus, 10 
respondents said that the contact employee's competence directly leads to a solution of the problem, whereas 12 respondents sequentially related the two elements with another element in between.

In the next step, the found associations are represented on a hierarchical value map, which represents the most important attributes, consequences, and values (conceptual meanings) and the linkages between them. A HVM normally consists of three different levels, which relate to the three concepts of meaning: personal value concepts are put at the top of the diagram, functional and psychosocial consequences are positioned near the middle and attributes are placed at the bottom of the map.

In order to facilitate the reading of the map, the researcher has to decide that the HVM only displays associations beyond a specific "cut-off" level, which means that linkages have to be mentioned by a certain number of respondents in order to be graphically represented. For example, a cut-off level of 1 means that every connection between constructs mentioned by respondents is graphically represented. The resulting HVM is "a mass of links and concepts that usually is unintelligible" (Christensen and Olson 2002, p. 484). The higher the chosen cut-off level is, the more linkages and constructs of meaning will disappear and the more interpretable the map will become. However, if the cut-off level is too high, too many constructs will have disappeared to make it worthwhile. Researchers, therefore, have to find a balance between data reduction and retention (Gengler et al. 1995) and between detail and interpretability (Christensen and Olson 2002) to create a clear and expressive map with sufficient information.

The HVM shown below (Figure 3) displays associations beyond the cut-off level of 3, which means that linkages have to be mentioned by at least 3 respondents in order to be graphically represented. This cut-off level was chosen as the resulting map keeps the balance between data reduction and retention and between detail and interpretability. 
(Take in Figure 3)

Figure 3 displays a complex cognitive structure, consisting of 9 attributes, 11 consequences, and 3 values. The size of the circle stands for the frequency respondents mentioned a certain cognitive concept. Thus, the most critical attributes are friendliness, competence, and motivation. Complainants want contact employees to give positive nonverbal signals ("friendliness"), to have sufficient product or service knowledge and the authority to handle their problems adequately ("competence"), and they want employees to be willing to try hard ("motivation"). As the width of the line in the HVM reveals, active listening and competence are strongly associated with the consequence "complaint handling". If employees listen actively and are competent, customers think that the complaint will be handled.

The main consequences are "take someone seriously", which is mainly influenced by the employee's courtesy, "problem handling" and "problem solution". Customers think that if employees take them seriously, this will lead to a problem solution which will lead to feelings of satisfaction. If employees take complainants seriously, they may continue the relationship with the company/service provider and demonstrate repeat purchase behaviour in the future ("loyalty"). Customers believe that they can assist employees in solving the problem if they are relaxed and have calmed down. Complainants often enter the complaint handling encounter in an angry mood which makes it difficult for customer contact employees to resolve complaints as customers are not open to rational explanations and arguments. The frontline employee's friendliness can help customers to feel more at ease and receive the impression of being in good hands so that they feel better ("well-being"). If contact employees are friendly, customers sense a good climate between the contact employees and themselves ("atmosphere") and they get the impression that employees are treating them well ("good treatment"). Customers also require sincerity in employees ("honesty") in order to 
develop trust ("trust"). Employees should also take sufficient time to handle the complaint ("take time").

The HVM also shows that a speedy complaint resolution will help customers save time which makes them feel satisfied and which allows them to devote attention to other issues ("concentrate on other issues"). According to the HVM, customers particularly want to satisfy the following values: "satisfaction", which was mentioned 12 times, "well-being" (7 times), and "security" (6 times). For customers to be able to feel secure employees should know their subject and have the authority to deal with the problem at hand ("competence").

\section{Discussion and Managerial Implications}

This research study reveals that if customers perceive frontline employees as competent, they also believe they will handle and ultimately solve their problem. Competence gives customers a feeling of security. Employees need to actively listen to their customers as this will create the feeling that the complaint is being taken seriously; "take someone seriously" was one of the most frequently discussed consequences by respondents. Respondents felt taken seriously if contact employees were courteous, ensured transparency and were open to suggestions (“openness"). Customers want to be taken seriously because they believe that the problem will be solved. If employees take customers seriously and show respect, customers may also decide to continue the relationship with the company/service provider and demonstrate repeat purchase behaviour.

The analysis of the hierarchical value map shows that customers have specific desire expectations: above all, complaining customers desire contact employees who are competent, which means that they should possess sufficient skills to handle complaints effectively. They should have knowledge about the product or service and they should know what needs to be done to solve the problem at hand. "Competence" was the most often mentioned attribute that 
respondents want employees to possess. Complaint handling competence is a resource that contact employees bring to the complaint handling encounter and that does not depend on the complaining customer's input during the encounter (Jaccard et al. 1989; Van Dolen et al. 2004). Complaint handling competence consists of social, professional, and methodological competence (Büdenbender and Strutz 1996). In particular, respondents want employees to have sufficient product or service knowledge and prior experience to interact successfully with them. This reflects the work of Becker and Wellins (1990) who found that customers want employees to have both an understanding of the company's products and services as well as those policies and procedures that relate to customer service.

Complaining customers desire contact employees who are genuinely friendly, courteous, honest, and who give the impression of being motivated and willing to help. Friendliness and motivation were the second and third most mentioned attributes. They illustrate the importance of contact employees having a complaint handling orientation, which can be defined as the willingness and inclination of customer contact employees to continuously improve their complaint handling performance. This helpful and friendly approach should be genuine as respondents believed that they would notice if employees feigned friendliness.

Customer contact employees also need to listen actively to what the complaining customer is saying. "Active listening" is an attribute that was mentioned frequently by respondents, which supports findings from the personal selling and sales management literature which shows that listening behaviour plays an important role for personal interactions (e.g. Clopton et al. 2001; De Ruyter and Wetzels 2000; Ramsey and Sohi 1997). Contact employees who listen actively, receive, process, and respond to messages in such a way that further communication is encouraged. Such individuals pay attention to both the speaker's verbal and nonverbal cues and they are also capable of providing both verbal and nonverbal feedback (Comer and Drollinger 1999). 
Customers also want contact employees to handle the complaint and solve the problem, which is the main reason for customers to get in contact with the company in the first place. To do this the complaint and the complainant have to be taken seriously. Respondents want employees to treat them courteously when the customer is being friendly and courteous to them. Importantly this requires organisations to identify and recruit individuals who are genuinely willing to help and to act on their behalf of their complaining customers.

\section{Limitations and Directions for Further Research}

This study was explorative in nature as it was the first to apply the paper and pencil version of the laddering technique to the issue of complaint handling and complaint satisfaction. The paper's aim was to give an in-depth insight into what matters for complaining customers by revealing several important constructs. Further research studies, however, should improve our knowledge of this topic.

Due to the explorative nature of the study in general and the scope and size of its sample in particular, the results outlined are tentative; the study involved a group of university students from one university and so the results cannot be generalised. Qualitative researchers, however, can enhance generalisability by carrying out further studies using similar data collection and analysis methods at other research sites using different research populations. By applying research findings to other contexts and by demonstrating existing connections and linkages, qualitative researchers engage in "moderatum generalization" (Bryman 2004, p. 285). This can demonstrate the validity of the findings beyond a particular research context and further research should be carried out using similar data collection and analysis methods at other research sites. While this study was conducted with postgraduate students enrolled in two business management courses, what is now needed is similar research with different 
sample populations. Results from these studies could then be compared and differences and similarities revealed.

Botschen et al. (1999) point to the fact that the paper-and-pencil version used for this study provides hardly any context information. As a consequence, the development of meaningful categories during content analysis is occasionally difficult to perform, especially if the researcher's pre-laddering knowledge about their respondents' cognitive categories is limited (Grunert and Grunert 1995). In addition, Botschen et al. (1999, p. 55) admit that "little is known about the validity and reliability of the procedure and the comparability of results obtained from traditional laddering interview (soft laddering) and paper-and-pencil laddering". Due to the lack of personal interviewing techniques (e.g. postulating the absence of an object or a state of being or evoking the situational context), an inevitable amount of richness of data is lost. Finally, the researcher has no control over the interviewing process himself (e.g. who really fills in the questionnaire?). Grunert et al. (2001, p. 76), therefore, suggest that future research should clarify "under which circumstances it may be safe to perform hard laddering, and when it appears necessary to employ soft laddering".

The results of the research study indicate that only a few respondents were able to reach the highest level of abstraction, and in comparable paper-and-pencil laddering studies (Botschen et al. 1999; Botschen and Hemetsberger 1998; Pieters et al. 1998), respondents came up with relatively few values like "feeling good", "harmony with yourself", and "satisfaction". Botschen and Hemetsberger (1998) suggest that researchers could conduct indepth laddering interviews to gather more and deeper information. Thus, research should also explore the use of semi-standardised, qualitative, in-depth one-on-one laddering interviews to learn more about the desired qualities of contact employees.

The means-end approach and the laddering technique are based on Kelly's Personal Construct Psychology (1991/1955). As a consequence, these methods are subject to the limitations of the theory (Gengler et al. 1995). All personal construct approaches depend on 
the ability and willingness of respondents to present their individuality, to reflect on their knowledge, and to verbalize their experiences. Banister et al. (1994), however, point out that many people may find this difficult. This may explain why only a few respondents were able to climb the ladder of abstraction.

A hierarchical value map only displays associations beyond a specific "cut-off" level, which means that associations have to be mentioned by a certain number of respondents in order to be graphically represented. However, Grunert and Grunert (1995) rightly argue that neither theoretical nor statistical criteria exist that help researchers decide which cut-off level they should choose. Further research might try to develop these criteria.

Manyiwa and Crawford (2002) point out that advocates of the means-end approach frequently assume that by merely linking attributes to consequences to values, "the link between consumers' values and behaviour (choice) has been established" (p.56) as well. However, an empirical basis for this hypothesis does not exist and Fiske and Taylor (1991) even question the ability of cognition to predict behaviour alone. Similarly, Grunert et al. (2001) are clear that the means-end approach alone cannot explain or predict behaviour. For this purpose, the model of cognitive structure has to be complemented by assumptions about cognitive processes as well and means-end chains should be integrated into a theory that takes into account such assumptions. They believe that means-end chains could be integrated into or compared with already existing theories on consumer behaviour such as the theory of reasoned action (Ajzen and Fishbein 1980; Fishbein and Ajzen 1975).

Other researchers believe that the difficulties with the means-end approach and the laddering method are both researchable and solvable (Grunert et al. 2001). It is likely that significant progress can be made within a relatively short time if fellow researchers could be attracted to these issues. 


\section{References}

Ajzen, Icek and Fishbein, Martin (1980), Understanding Attitudes and Predicting Behavior, Englewood Cliffs, NJ: Prentice-Hall.

Bagozzi, Richard P. and Dabholkar, Pratibha, A. (1994), "Consumer Recycling Goals and their Effect on Decisions to Recycle: A Means-End Chain Analysis”, Psychology and Marketing, Vol. 11, No. 4, pp. 313-340.

Banister, Peter, Burman, Erica, Parker, Ian, Taylor, Maye and Tindall, Carol (1994), Qualitative Methods in Psychology - A Research Guide, Maidenhead: Open University Press.

Becker, Wendy S. and Wellins, Richard S. (1990), “Customer Service Perceptions and Reality”, Training and Development Journal, Vol. 44, No. 3, pp. 49-51.

Bitner, Mary J., Booms, Bernard H. and Tetreault, Mary S. (1990), “The Service Encounter: Diagnosing Favorable and Unfavorable Incidents", Journal of Marketing, Vol. 54, January, pp. 71-84.

Blodgett, Jeffrey G., Wakefield, Kirk L. and Barnes, James H. (1995), “The Effects of Customer Service on Consumer Complaining Behavior", Journal of Services Marketing, Vol. 9, No. 4, pp.31-42.

Boshoff, Christo and Allen, Janine (2000), “The Influence of Selected Antecedents on Frontline Staff's Perceptions of Service Recovery Performance”, International Journal of Service Industry Management, Vol. 11, No. 1, pp.63-90. 
Botschen, Günther and Hemetsberger, Andrea (1998), "Diagnosing Means-End Structures to Determine the Degree of Potential Marketing Program Standardization”, Journal of Business Research, Vol. 42, No. 2, pp. 151-159.

Botschen, Günther and Thelen, Eva M. (1998), "Hard Versus Soft Laddering: Implications for Appropriate Use”. In: Balderjahn, Ingo, Mennicken, C. and Vernette, Eric, eds., New Developments and Approaches in Consumer Behaviour Research, Stuttgart: SchäfferPoeschel Verlag, pp. 321-339.

Botschen, Günther, Thelen, Eva M., Pieters, Rik (1999), “Using Means-End Structures for Benefit Segmentation", European Journal of Marketing, Vol. 33, No. 1/2, pp. 38-58.

Bryman, Alan (2004), Social Research Methods 2nd Edition, Oxford: Oxford University Press.

Büdenbender, Ulrich and Strutz, Hans (1996), Gabler Lexikon Personal [Gabler encyclopedia personnel], Wiesbaden: Gabler Verlag.

Chang, Tien M. (1986), "Semantic Memory: Facts and Models”, Psychological Bulletin, Vol. 99, No. 2, pp.199-220.

Christensen, Glenn L. and Olson, Jerry C. (2002), “Mapping Consumers' Mental Models with ZMET," Psychology and Marketing, Vol. 19, No. 6, pp. 477-502.

Chung-Herrera, Beth G., Goldschmidt, Nadav and Hoffman, Douglas K. (2004), “Customer and Employee Views of Critical Service Incidents", Journal of Services Marketing, Vol. 18, No. 4, pp. 241-254. 
Clopton, Stephen W., Stoddard, James E. and Clay, Jennifer W. (2001), “Salesperson Characteristics Affecting Consumer Complaint Responses", Journal of Consumer Behaviour, Vol.1, No. 2, pp. 124-139.

Comer, Lucette B. and Drollinger, Tanja (1999), “Active Empathetic Listening and Selling Success: A Conceptual Framework", Journal of Personal Selling \& Sales Management, Vol. 19, No. 1, pp. 15-29.

Cranage, David (2004), "Plan to Do it Right: And Plan for Recovery”, International Journal of Contemporary Hospitality Management, Vol. 16, No. 4, pp. 210-219.

De Ruyter, Ko and Wetzels, Martin (2000), “The Impact of Perceived Listening Behavior in Voice-to-Voice Service Encounters", Journal of Service Research, Vol. 2, No. 3, pp. 276-284.

Deeter-Schmelz, Dawn R., Kennedy, Karen Norman and Goebel, Daniel J. (2002), "Understanding Sales Manager Effectiveness - Linking Attributes to Sales Force Values", Industrial Marketing Management, Vol. 31, No. 7, pp. 617-626.

Fishbein, Martin and Ajzen, Icek (1975), Belief, Attitude, Intention and Behavior, Reading, MA: Addison-Wesley.

Fiske, Susan T. and Taylor, Shelley E. (1991), Social Cognition, New York, NY: McGrawHill.

Folkes, Valerie S. (1984), “Consumer Reactions to Product Failure: An Attributional Approach”, Journal of Consumer Research, Vol. 10, March, pp. 398-409.

Gengler, Charles E. and Reynolds, Thomas J. (1993), "LADDERMAP: A Software Tool for Analyzing Laddering Data, Version 5.4"[Computer software]. 
Gengler, Charles E. and Reynolds, Thomas J. (1995), “Consumer Understanding and Advertising Strategy: Analysis and Strategic Translation of Laddering Data", Journal of Advertising Research, Vol. 35, July/August, pp. 19-33.

Gengler, Charles E., Klenosky, David B. and Mulvey, Michael S. (1995), "Improving the Graphic Representation of Means-End Results", International Journal of Research in Marketing, Vol. 12, No. 3, pp. 245-256.

Goldenberg, Marni A., Klenosky, David B., O'Leary, Joseph T. and Templin, Thomas J. (2000), “A Means-End Investigation of Ropes Course Experiences”, Journal of Leisure Research, Vol. 32, No. 2, pp. 208-224.

Grunert Klaus G. and Grunert, Suzanne C. (1995), "Measuring Subjective Meaning Structures by the Laddering Method: Theoretical Considerations and Methodological Problems", International Journal of Research in Marketing, Vol. 12, No. 3, pp. 209-225.

Grunert Klaus G., Beckmann, Suzanne C. and Sørensen, Elin (2001), “Means-End Chains and Laddering: An Inventory of Problems and an Agenda for Research”. In: Reynolds, Thomas J. and Olson, Jerry C., eds., Understanding Consumer Decision Making - The Means-End Approach to Marketing and Advertising Strategy, Mahwah, NJ: Lawrence Erlbaum Associates, pp. 63-90.

Gutman, Jonathan (1982), “A Means-End Chain Model Based on Consumer Categorization Processes", Journal of Marketing, Vol. 46, Spring, pp. 60-72.

Hart, Christopher W. L, Heskett, James L. and Sasser Jr., W. Earl (1990), “The Profitable Art of Service Recovery", Harvard Business Review, Vol. 68, July-August, pp.148-156. 
Hartline, Michael D. and Ferrell, Orville C. (1996), "The Management of Customer-Contact Service Employees: An Empirical Investigation”, Journal of Marketing, Vol. 60, October, pp. 52-70.

Hennig-Thurau, Thorsten (1999), "Beschwerdezufriedenheit: Empirische Analyse der Wirkungen und Determinanten einer Schlüsselgröße des Beziehungsmarketing“ [Analyzing the Determinants and Consequences of Complaint Satisfaction], Jahrbuch der Absatz- und Verbrauchsforschung, Vol. 45, No. 2, pp. 214-240.

Herrmann, Andreas (1996), Nachfrageorientierte Produktgestaltung - ein Ansatz auf Basis der "Means End" - Theorie [Demand Oriented Product Design - An Approach Based on the Means End Theory], Wiesbaden: Gabler Verlag.

Holloway, Betsy B. and Beatty, Sharon E. (2003), "Service Failure in Online Retailing - A Recovery Opportunity”, Journal of Service Research, Vol. 6, No.1, pp. 92-105.

Jaccard, James, Brinberg, David and Dittus, Patricia J. (1989), "Couple Decision Making: Individual- and Dyadic-Level Analysis". In: Brinberg, David and Jaccard, James, eds., Dyadic Decision Making, New York, NY: Springer, pp. 36-50.

Kelly, George A. (1991/1955), The Psychology of Personal Constructs. 2 Volumes, London/New York, NY: Routledge (Reprint 1991; Original 1955: New York, NY: Norton).

Kim, Chulmin, Kim, Sounghie, Im, Subin and Shin, Changhoon (2003), “The Effect of Attitude and Perception on Consumer Complaint Intentions", Journal of Consumer Marketing, Vol. 20, No. 4, pp. 352-371. 
Lewis, Barbara R. and McCann, Pamela (2004), “Service Failure and Recovery: Evidence from the Hotel Industry", International Journal of Contemporary Hospitality Management, Vol. 16, No. 1, pp. 6-17.

Manyiwa, Simon and Crawford, Ian (2002), “Determining Linkages Between Consumer Choices in a Social Context and the Consumer's Values: A Means-End Approach", Journal of Consumer Behaviour, Vol. 2, No. 1, pp. 54-70.

Maxham III, James G. and Netemeyer, Richard G. (2003), "Firms Reap What They Sow: The Effects of Shared Values and Perceived Organizational Justice on Customers' Evaluations of Complaint Handling”, Journal of Marketing, Vol. 67, January, pp. 4662.

McAlister, Debbie Thorne and Erffmeyer, Robert C. (2003), “A Content Analysis of Outcomes and Responsibilities for Consumer Complaints to Third-Party Organizations", Journal of Business Research, Vol. 56, No. 4, pp. 341-351.

McCollough, Michael A., Berry, Leonard L. and Yadav, Manjit S. (2000), “An Empirical Investigation of Customer Satisfaction After Service Failure and Recovery”, Journal of Service Research, Vol. 3, No. 2, pp. 121-137.

Naylor, Gillian (2003), “The Complaining Customer: A Service Provider's Best Friend?”, Journal of Consumer Satisfaction, Dissatisfaction and Complaining Behavior, Vol. 16, pp. 241-248.

Norton, John A. and Reynolds, Thomas J. (2001), “The Application of Means-End Theory in Industrial Marketing”. In: Reynolds, Thomas J. and Olson, Jerry C., eds., Understanding Consumer Decision Making - The Means-End Approach to Marketing and Advertising Strategy, Mahwah, NJ: Lawrence Erlbaum Associates, pp. 319-334. 
Olson, Jerry C. and Reynolds, Thomas J. (1983), “Understanding Consumers' Cognitive Structures: Implications for Marketing Strategy”. In: Percy, Larry and Woodside, Arch G., eds., Advertising and Consumer Psychology, Lexington, MA: Lexington Books, pp. 77-90.

Olson, Jerry C. and Reynolds, Thomas J. (2001), “The Means-End Approach to Understanding Consumer Decision Making”. In: Reynolds, Thomas J. and Olson, Jerry C., eds., Understanding Consumer Decision Making - The Means-End Approach to Marketing and Advertising Strategy, Mahwah, NJ: Lawrence Erlbaum Associates, pp. 3-23.

Parasuraman A., Zeithaml, Valarie A. and Berry, Leonard L. (1985), “A Conceptual Model of Service Quality and its Implications for Future Research”, Journal of Marketing, Vol. 49, Fall, pp. 41-50.

Peter, J. Paul, Olson, Jerry C. and Grunert, Klaus C. (1999), Consumer Behaviour and Marketing Strategy (European Edition), London: McGraw-Hill.

Pieters, Rik, Botschen, Günther and Thelen, Eva. M. (1998), “Customer Desire Expectations about Service Employees: An Analysis of Hierarchical Relations", Psychology \& Marketing, Vol. 15, No. 8, pp. 755-773.

Pieters, Rik, Baumgartner, Hans and Allen, Doug (1995), “A Means-End Chain Approach to Consumer Goal Structures," International Journal of Research in Marketing, Vol. 12, No. 3, pp. 227-244.

Ramsey, Rosemary P. and Sohi, Ravipreet S. (1997), "Listening to Your Customers: The Impact of Perceived Salesperson Listening Behavior on Relationship Outcomes”, Journal of the Academy of Marketing Science, Vol. 25, No. 2, pp. 127-137. 
Reichheld, Frederick F. and Sasser, Jr. W Earl (1990), “Zero Defections: Quality Comes to Services”, Harvard Business Review, Vol. 68, September-October, pp. 101-111.

Reynolds, Thomas J. and Gutman, Jonathan (1988), “Laddering Theory, Method, Analysis, and Interpretation", Journal of Advertising Research, Vol. 28, February/March, pp. $11-31$.

Reynolds, Thomas J. and Rochon, John P. (2001), “Consumer Segmentation Based on Cognitive Orientations: The Chemlawn Case”. In: Reynolds, Thomas J. and Olson, Jerry C., eds., Understanding Consumer Decision Making - The Means-End Approach to Marketing and Advertising Strategy, Mahwah, NJ: Lawrence Erlbaum Associates, pp. 283-298.

Reynolds, Thomas J., Gengler, Charles E. and Howard, Daniel J. (1995), “A Means-End Analysis of Brand Persuasion Through Advertising", International Journal of Research in Marketing, Vol. 12, No. 3, pp. 257-266.

Reynolds, Thomas J, Rochon, John P. and Westberg, Steven J. (2001), “A Means-End Chain Approach to Motivating the Sales Force: The Mary Kay Strategy”. In: Reynolds, Thomas J. and Olson, Jerry C., eds., Understanding Consumer Decision Making - The Means-End Approach to Marketing and Advertising Strategy, Mahwah, NJ: Lawrence Erlbaum Associates, pp. 269-282.

Richins, Marsha L. (1982), “An Investigation of Consumer Attitudes Toward Complaining”. In: Mitchell, Andrew, ed., Advances in Consumer Research, Provo, UT: Association for Consumer Research, pp. 502-506.

Rokeach, Milton J. (1973), The Nature of Human Values, New York, NY: Free Press. 
Singh, Jagdip (1990), "Voice, Exit, and Negative Word-of-Mouth Behaviors: An Investigation Across Three Service Categories", Journal of the Academy of Marketing Science, Vol. 18, Winter, pp. 1-15.

Singh, Jagdip and Widing II, Robert E. (1991), "What Occurs Once Consumers Complain? A Theoretical Model for Understanding Satisfaction/Dissatisfaction Outcomes for Complaint Responses", European Journal of Marketing, Vol. 25, No. 5, pp. 30-46.

Stauss, Bernd (1999), "Kundenbindung durch Beschwerdemanagement“ [Customer Retention Through Complaint Management]. In: Bruhn, Manfred and Homburg, Christian, eds., Handbuch Kundenbindungsmanagement 2nd Edition [The Customer Retention Management Handbook], Wiesbaden: Gabler Verlag, pp. 213-238.

Stauss, Bernd (2002), "The Dimensions of Complaint Satisfaction: Process and Outcome Complaint Satisfaction Versus Cold Fact and Warm Act Complaint Satisfaction”, Managing Service Quality, Vol. 12, No. 3, pp. 173-183.

Strauss, Anselm and Corbin, Juliet M. (1998), Basics of Qualitative Research: Techniques and Procedures for Developing Grounded Theory, Thousand Oaks, CA: Sage.

Van Dolen, Willemijn, De Ruyter, Ko and Lemmink, Jos (2004), “An Empirical Assessment of the Influence of Customer Emotions and Contact Employee Performance on Encounter and Relationship Satisfaction”, Journal of Business Research, Vol. 57, No. 4, pp. 437-444.

Van Rekom, Johan and Wierenga, Berend (2002), Means-End Relations: Hierarchies or Networks? An Inquiry into the (A)symmetry of Means-End Relations. ERIM Report Series Research in Management, Rotterdam: Erasmus Research Institute of Management. 
Walker, Beth A. and Olson, Jerry C. (1991), "Means-End Chains: Connecting Products with Self," Journal of Business Research, Vol. 22, No. 2, pp. 111-118.

Wirtz, Jochen and Mattila, Anna S. (2004), “Consumer Responses to Compensation, Speed of Recovery and Apology After a Service Failure”, International Journal of Service Industry Management, Vol. 15, No. 2, pp. 150-166.

Yim, Chi K., Gu, Flora F., Chan, Kimmy W. and Tse, David K. (2003), “Justice-Based Service Recovery Expectations: Measurement and Antecedents”, Journal of Consumer Satisfaction, Dissatisfaction and Complaining Behavior, Vol. 16, pp. 36-52.

Zeithaml, Valarie A., Berry Leonard L. and Parasuraman, A. (1993), “The Nature and Determinants of Customer Expectations of Services", Journal of the Academy of Marketing Science, Vol. 21, No. 1, pp. 1-12. 


\section{Figure 1. Laddering Instruction for Paper-and-Pencil Version of Laddering (adapted from Pieters et al. (1998, pp. 759-760))}

Think about the behaviours or characteristics of customer contact employees that are important to you. Please do not describe the behaviours or characteristics that contact employees actually perform or have, but how you would like them to act or be. On the next page four sequences of boxes appear. Each sequence contains four boxes. The text above the first box in each sequence reads "I would like the contact employee to be ... or to act ..." Write in the first box of the first sequence the desired characteristic or behaviour of the contact employee that comes first to mind. Please be as specific and as exact as possible. Now think about another characteristic or behaviour that you would like the contact employee to have or to display. Write this in the first box of the second sequence, and so on, until you have written your desires in the first boxes of the four sequences. Once you have done this, proceed to the second box of the first sequence. The text above this box reads: “... that is important to me because..." Indicate in this box why the characteristic or behaviour of the contact employee is important to you. After you have indicated that, proceed to the third box of the first sequence. The text above this box reads: “... and this is important to me because..." Indicate in the third box, why what you indicated in the second box is important to you in this situation. Please then complete the fourth box in the same way. When you have completed the first sequence, proceed to the second sequence, and so forth, until you have completed all four sequences. If you really do not know why something that you indicated in a previous box is important to you, you can leave the following box open. However, we would appreciate it if you try to be as complete as possible. 
Figure 2. Paper-and-Pencil Version of Laddering (adapted from Pieters et al. (1998, p. 760) and Botschen and Hemetsberger (1998, p. 154))

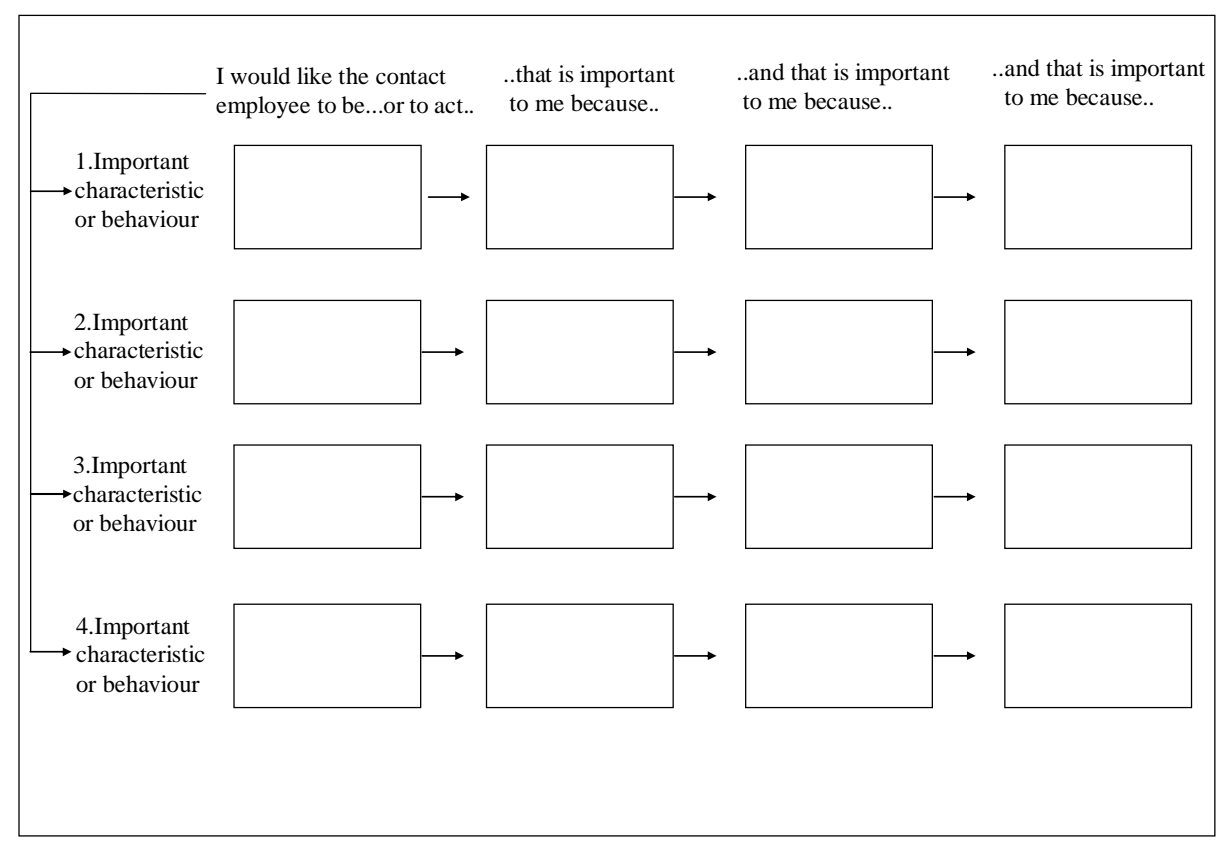


Figure 3. Hierarchical Value Map of Complaining Customers (Cutoff Level 3)

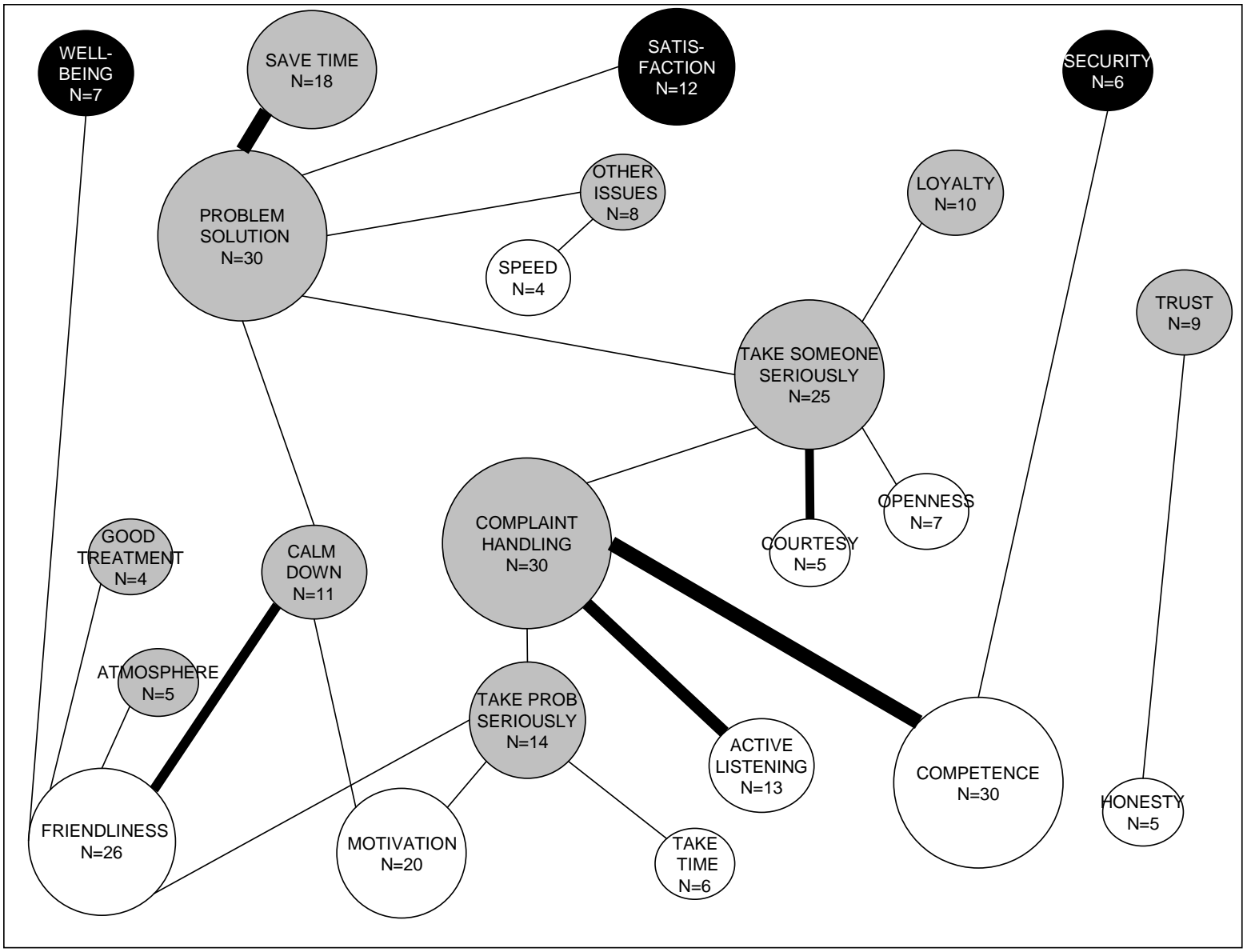

Note: White circles represent attributes, grey circles stand for consequences, and black circles represent values.

The following two abbreviations were used: TAKE PROB SERIOUSLY = Take problem seriously; OTHER ISSUES $=$ Concentrate on other issues. 
Table 1. Characteristics of Sample

\begin{tabular}{|l|l|l|l|l|l|l|}
\hline & $\begin{array}{l}\text { Number of } \\
\text { respondents }\end{array}$ & \multicolumn{2}{|c|}{ Gender } & \multicolumn{3}{c|}{ Age } \\
\hline & & Female & Male & Min & Max & Average \\
\hline $\begin{array}{l}\text { Laddering } \\
\text { Questionnaires }\end{array}$ & 40 & $\begin{array}{l}28 \\
(70 \%)\end{array}$ & $\begin{array}{l}12 \\
(30 \%)\end{array}$ & 19 & 39 & 24.3 \\
\hline
\end{tabular}

Table 2. Overview of all Attributes

\begin{tabular}{|c|c|c|}
\hline Name of Attribute & $\begin{array}{c}\text { Number of } \\
\text { times } \\
\text { mentioned } \\
\text { (in ladders) }\end{array}$ & Characteristics \\
\hline Competence & 33 & $\begin{array}{l}\text { Employees should have sufficient service (product) knowledge and } \\
\text { the authority to handle customer problems adequately. }\end{array}$ \\
\hline Friendliness & 27 & Employees should smile and give positive nonverbal cues. \\
\hline Motivation & 22 & Employees should be willing to try hard and to spare no effort. \\
\hline Active Listening & 14 & $\begin{array}{l}\text { Contact employees should listen to what their customers are saying, } \\
\text { ask questions and hear customers out. }\end{array}$ \\
\hline Openness (Employee) & 7 & $\begin{array}{l}\text { Customers want employees to ensure transparency and be open to } \\
\text { suggestions. }\end{array}$ \\
\hline Courtesy & 6 & Employees should genuinely care about the customer. \\
\hline Empathy & 6 & $\begin{array}{l}\text { Employees should be willing to take the customer's perspective and } \\
\text { to understand the customer's annoyance. }\end{array}$ \\
\hline Take time & 6 & Employees should take sufficient time to handle the complaint. \\
\hline Honesty & 5 & Employees should be sincere. \\
\hline Speed & 5 & Employees should handle the problem quickly. \\
\hline Reliability & 2 & Employees should keep promises. \\
\hline Responsibility & 2 & Employees should take responsibility for the problem. \\
\hline Objectivity & 1 & $\begin{array}{l}\text { Employees should give the impression of being unbiased and } \\
\text { characterised by a matter-of-fact-orientation. }\end{array}$ \\
\hline Accurateness & 1 & Employees should perform exactly to a standard and free from error. \\
\hline Stay Calm & 1 & Employees should be relaxed. \\
\hline
\end{tabular}


Table 3. Overview of all Consequences

\begin{tabular}{|c|c|c|}
\hline Name of Consequence & $\begin{array}{c}\text { Number of } \\
\text { times } \\
\text { mentioned } \\
\text { (in ladders) }\end{array}$ & Characteristics \\
\hline Solution & 49 & $\begin{array}{l}\text { Customers want to get the impression that contact employees will } \\
\text { solve their problems. }\end{array}$ \\
\hline Complaint handling & 49 & $\begin{array}{l}\text { Customers want to believe that contact employees will handle the } \\
\text { complaint. }\end{array}$ \\
\hline Take someone seriously & 37 & $\begin{array}{l}\text { Customers want to get the impression that employees take them } \\
\text { seriously. }\end{array}$ \\
\hline Save time & 23 & Customers can save time. \\
\hline Take problem seriously & 17 & $\begin{array}{l}\text { Contact employees give the impression of taking the complaining } \\
\text { customer's concerns seriously. }\end{array}$ \\
\hline Calm down & 15 & $\begin{array}{l}\text { Customers can calm down and relax from the nerve-racking } \\
\text { experience. }\end{array}$ \\
\hline Loyalty & 13 & $\begin{array}{l}\text { Customers are interested in continuing the relationship with the } \\
\text { company/service provider and to demonstrate repeat purchase } \\
\text { behaviour. }\end{array}$ \\
\hline $\begin{array}{l}\text { Concentrate on other } \\
\text { issues }\end{array}$ & 11 & Customers can devote attention to other issues. \\
\hline Trust & 10 & Customers have confidence in the contact employee. \\
\hline Atmosphere & 6 & $\begin{array}{l}\text { Customers sense a good climate between contact employees and } \\
\text { themselves. }\end{array}$ \\
\hline Good treatment & 4 & Customers get the impression that employees treat them well. \\
\hline Learning & 3 & Customers know more about product or service. \\
\hline Openness (Customer) & 3 & Customers can be open with contact employees. \\
\hline Save money & 3 & Customer can save money. \\
\hline Forgiveness & 2 & Customers can cease to feel resentment against contact employees. \\
\hline
\end{tabular}


Table 4. Overview of all Values

\begin{tabular}{|l|c|l|}
\hline \multicolumn{1}{|c|}{ Name of Value } & $\begin{array}{c}\text { Number of } \\
\text { times } \\
\text { mentioned } \\
\text { (in ladders) }\end{array}$ & \\
\hline Satisfaction & 13 & Customers want to be satisfied. \\
\hline Security & 9 & Customers want to have certainty and to be freed from doubt. \\
\hline Well-being & 8 & Customers want to be in good hands and to feel happy. \\
\hline Justice & 5 & Customers want to feel equitably treated. \\
\hline Hedonism & 2 & Customers are pleasure-seeking and want to enjoy life and have fun. \\
\hline Success & 2 & Customer wants to be successful. \\
\hline Better World & 1 & Customers want to take responsibility for a better world. \\
\hline Harmony & 1 & Customers want a harmonious world. \\
\hline
\end{tabular}


Table 5. Extract from Implication Matrix

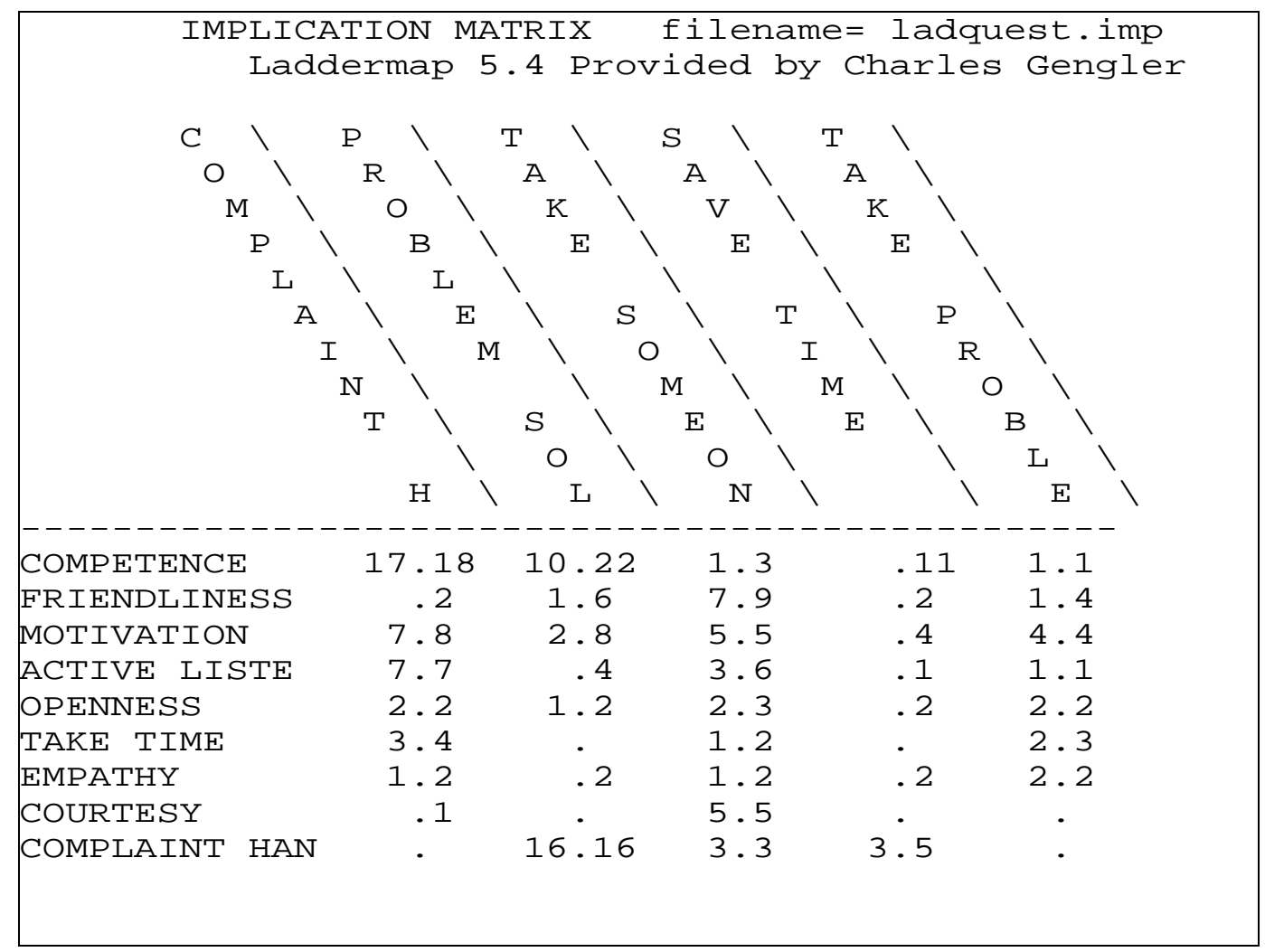

